\title{
Reconstructing snow avalanches in the Southeastern Pyrenees
}

\author{
E. Muntán ${ }^{1}$, C. García ${ }^{2}$, P. Oller ${ }^{2}$, G. Martí ${ }^{2}$, A. García ${ }^{3}$, and E. Gutiérrez ${ }^{1}$ \\ ${ }^{1}$ Dendroecology, Department of Ecology, University of Barcelona, Diagonal 645, 08028 Barcelona, Spain \\ ${ }^{2}$ Geological Hazards Unit, Geological Institute of Catalonia, Balmes 209-211, 08006 Barcelona, Spain \\ ${ }^{3}$ Group of Climatology, Department of Physical Geography and Regional Geographical Analysis, \\ University of Barcelona, Montalegre 6, 08001 Barcelona, Spain
}

Received: 4 January 2008 - Revised: 4 May 2009 - Accepted: 26 August 2009 - Published: 28 September 2009

\begin{abstract}
A regional study of snow avalanche processes was undertaken in the SE Pyrenees. Dendrogeomorphology was used to date and reconstruct large-scale snow avalanche events that occurred in the last four decades. Dendrochronological analyses yielded the dates of nine winters when avalanches occurred in the recent past in six studied avalanche paths. Some of these avalanches were already known, but others had not been documented. In one case, the existing avalanche path map was improved with the dendrogeomorphological information of a larger past event. As a result of the dendrogeomorphological analyses, evidence for three regional-scale major avalanche years was identified in the SE Pyrenees from 1971 to 2004: 1971-1972, 1995-1996 and 2002-2003. The specific synoptic atmospheric situations and the most likely nivometeorological and snowpack conditions that released these major avalanches were determined using weather data for the seasons of major avalanche releases. In 1971-1972 the snow avalanche episode was characterized by a deep trough crossing the Pyrenees. In 19951996 a variety of meteorological situations produced several episodes of major avalanches. In 2002-2003 the more significant of two episodes was attributed to a north advection pumping an arctic air mass over the Pyrenees. The 19951996 avalanche season proved to be the most notable in the four past decades in the Pyrenees.
\end{abstract}

\section{Introduction}

In recent times, the southern Pyrenees have undergone a profound land-use and economic transformation. Traditional rural society has given way to a growing leisure industry related

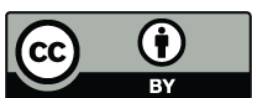

Correspondence to: E. Muntán (emuntan@ub.edu) to winter sports and mountain recreation in general. Rapid urbanisation and the resulting population densities have increased the number of people at risk in these areas. In 19951996 a large number of avalanches occurred in the Pyrenees. An avalanche warning system (avalanche forecast) prevented human casualties, however there was considerable damage to forests and infrastructure.

For hazard analysis and risk prevention in alpine and subalpine mountain areas, knowledge of snow avalanche characteristics is of paramount importance. To this end, present and past events must be researched in order to obtain information on avalanche extent, frequency and intensity. In every avalanche path, snow avalanches can attain different extents depending on interactions between terrain, weather conditions and existing snowpack structure. Small avalanches take place regularly, but large avalanches occur less frequently. Study of historical documents, interviews with local people, winter monitoring, meteorological data, field survey and avalanche path mapping are some of the conventional means to characterize snow avalanches. Dendrogeomorphological analysis of trees at avalanche sites is helpful in providing information about the return period and extent of avalanche events where these data are lacking.

Temporal and spatial characteristics of snow avalanches can be reconstructed by dating tree-ring responses caused by past events. Trees growing in mountain environments can be affected by a variety of natural disturbances (biological and non-biological). Different kinds of damage produce similar responses and thus similar tree-ring evidence. After a thorough dendrochronological dating process, those treering features not caused by snow avalanches are discarded and thus clues to the occurrence of past events may be obtained from evidence of disturbances and spatial distribution of trees at avalanche sites.

The usefulness of dendrochronological techniques in snow avalanche research has been demonstrated since the

Published by Copernicus Publications on behalf of the European Geosciences Union. 
beginnings of dendrogeomorphology (e.g.: Potter, 1969; Burrows and Burrows, 1976; Butler, 1979; Carrara, 1979). The most common features used by these researchers were scars on trees, changes in growth patterns from concentric to eccentric, appearance of reaction wood, abrupt growth disturbances (increase or decrease in growth rate), age of trees in naturally reforested paths, year of death of trees in debris, and breakage of stems or branches. Recent dendrogeomorphological works on snow avalanches continue to use these features to date events (e.g. Jenkins and Hebertson, 2003; Dubé et al., 2004; Germain et al., 2005; Stoffel et al., 2006; Casteller et al., 2007; Mundo et al., 2007; Reardon et al., 2008).

Snow avalanches have been poorly documented in the Pyrenees. Despite some pioneering mitigation work in the central Pyrenees in the early twentieth century, the study and management of snow avalanches was not undertaken until the 1980s (Muñoz, 1980; Furdada, 1996). The significant avalanche season 1995-1996 raises two main questions: was 1995-1996 such an extraordinary avalanche season? Had there been any similar avalanche seasons in the recent past? The present work seeks to answer these questions. Specifically our objectives were to: 1) date and reconstruct the spatial extent of recent past avalanches using dendrogeomorphological methods in a set of six selected avalanche paths; and 2) determine the synoptic atmospheric patterns releasing major avalanches and their regional extent.

Our findings will be helpful to land-use planners who can utilize the information to develop more rational avalanche protection strategies and implement measures to mitigate snow avalanche risk. With respect to this, details on the dendrogeomorphological methodology, its strengths and weaknesses, are also discussed.

\section{Study region}

The Pyrenees mountain range extends over $450 \mathrm{~km}$ from the Mediterranean Sea to the Atlantic Ocean and forms the isthmus that links the Iberian Peninsula to the rest of the Eurasian continent. The high Pyrenees range between 2000 and $3000 \mathrm{~m}$ in altitude reaching a maximum of $3404 \mathrm{~m}$ and they are about $120 \mathrm{~km}$ wide in the middle of the chain. The amplitude and the altitude of the Pyrenees diminish dramatically when the mountains approach either the Atlantic Ocean or the Mediterranean Sea. Two main kinds of relief can be broadly differentiated: elevated areas with abrupt peaks but having vertical drops not exceeding $700 \mathrm{~m}$, and valley areas having a flatter relief but with altitude variations higher than $1500 \mathrm{~m}$ in some cases.

Our study area was specifically located on the southeastern part of the range (Pyrenees of Catalonia), an area of about $150 \mathrm{~km}$ in length, $52 \mathrm{~km}$ wide in the western part and $19 \mathrm{~km}$ wide in the eastern part (Fig. 1). In this region, the highest mountain villages are situated at an altitude of $1500 \mathrm{~m}$. The highest roads that are open in winter are located at an altitude of $2300 \mathrm{~m}$ and nine alpine ski resorts are distributed at altitudes exceeding $1500 \mathrm{~m}$. The "Pica d'Estats" at an altitude $3143 \mathrm{~m}$ is the highest peak in the area.

The peculiar geographical features that shape the Pyrenees play a major role in the climatic conditions affecting the whole chain. The zonal disposition of the axial range retains polar and arctic maritime air masses from north advections, and tropical maritime air masses from the south and southwest. The meridian valley configuration favours the penetration and the placement of unstable air masses, i.e. the forced lifts caused by the relief may sometimes result in heavy and persistent snowfalls. Because of the proximity of the Pyrenees to the Mediterranean Sea and the Atlantic Ocean, temperatures are less extreme than in inland ranges. Interestingly, there are extensive rain shadows close to the Mediterranean. Finally, the massif is a boundary between the humid oceanic climate and the subtropical dry climate due to its relatively low latitude.

Despite the small size of the study area, three different climatic conditions are found: Oceanic, Continental and Mediterranean. The northwestern part of the study area is characterized by a humid oceanic climate. Precipitations are abundant and show a regular interannual distribution. The total amount of fresh snow at $2200 \mathrm{~m}$ altitude is about 500$600 \mathrm{~cm}$ per year. The oceanic influence crosses the main divide and extends few $\mathrm{km}$ to the south. However, the climate becomes more continental south of the main divide. Winter is the driest season and snow precipitation increases in the equinoctial periods, while interannual variability of precipitation increases. The total amount of fresh snow at $2200 \mathrm{~m}$ altitude slightly exceeds $250 \mathrm{~cm}$ per year. Predominant winds come from the north and northwest often with gusts over $100 \mathrm{~km} \mathrm{~h}^{-1}$. The Mediterranean Sea plays a crucial role in the climate in the eastern part of the Pyrenees. Thus heavy snowfalls can occur because of humid air masses from the Mediterranean Sea. Interannual variability of snowfalls is high. The total amount of fresh snow at $2200 \mathrm{~m}$ altitude is about $350-450 \mathrm{~cm} \mathrm{yr}^{-1}$. The formation of persistent lows over the lee-side of the Alps and the Gulf of Lions gives rise to prevailing winds from the north. Maximum wind gusts may occasionally exceed $200 \mathrm{~km} \mathrm{~h}^{-1}$ at $2200 \mathrm{~m}$ altitude.

According to weather and snow conditions the study area has been divided into 7 nivometeorological regions (Fig. 1). Given the absence of long meteorological records for the area, these regions do not constitute a strict climatic classification, but are the result of 15 years of avalanche forecasting in the Catalan Pyrenees. They fall into regions of different climatic influence. Oceanic: Aran-Northern border of Pallaresa (AP). Continental: Ribagorçana-Vall Fosca (RF), Pallaresa (PL), Perafita-Puigpedrós (PP) and V. N. Cadí Moixeró (NC). Mediterranean: Prepirineu (PR) and Ter-Freser (TF). 


\section{Dendrogeomorphological study sites}

Six snow avalanche paths were selected to conduct a dendrogeomorphological study. These were distributed over the area to provide information for the whole territory (Fig. 1). Some characteristics of the study sites appear in Table 1. For the purpose of this research, the sites were chosen in forested paths. Potential treeline altitude has been fixed at $\sim 2200$ $2450 \mathrm{~m}$ altitude in the Pyrenees (Carreras et al., 1996). The most widely distributed tree species growing at the highest altitudes (from 1600-2300/2500 m) is Pinus uncinata Ramond ex DC. in Lam et DC. (mountain pine). At lower elevations, other conifers as Pinus sylvestris $\mathrm{L}$. (Scots pine) and Abies alba Mill. (silver fir) can also be found. All the dated avalanches in this study were naturally released.

Avalanche Path 1 (AP 1, Núria) is located near the eastern end of the high Pyrenees, in the Núria valley. This path has a broad, concave starting zone, a narrow track and an unconfined runout. A mountain pine forest begins some meters below the starting zone, at $2200 \mathrm{~m}$ altitude. In the runout major avalanches affect the rack railway that connects the valley villages to the tourist resort of Vall de Núria. The first dendrogeomorphological study on snow avalanches in the Pyrenees was performed in this avalanche path (Muntán et al., 2004).

Avalanche Path 2 (AP 2, Ticó) starts at the top of a north facing, rocky wall with a snow corridor that is adjacent to a steep scree slope. The mountain pine forest in this path starts a few meters below the base of the rocky wall where the scree slope recedes (at $2200 \mathrm{~m}$ ). Beneath the middle track, the avalanche path becomes more confined ending up in a narrow runout. This avalanche path does not affect human dwellings.

Avalanche Path 3 (AP 3, Tor) is located in a remote area near the border of Andorra. This path has a concave starting zone adjacent to a narrow track. Avalanches in this path can take different trajectories in the final stretch. Either they are hedged in the mountain torrent which bends abruptly to the west, or overshoot the torrent talveg and invade a flat pasture surface straight ahead. The forest is mainly composed of mountain pine, but some Scots pine appear below $2150 \mathrm{~m}$ altitude.

In Avalanche Path 4 (AP 4, Virós) iron mining which started about 1500 years BP (High-Mountain Archaeology Group, Department of Prehistory, Autonomous University of Barcelona, personal communication, 2004) inhibited the growth of forests until the XIX century, sometime between 1850 and 1880 (A. Pèlachs, personal communication, 2004). Nowadays, the dominant species of this forest is also mountain pine (that grows up to treeline at $2250 \mathrm{~m}$ ). The topography of this avalanche path is uneven, i.e. there are a number of mining deposits in the middle track. It is reasonable to assume that the majority of avalanches stop above this zone because of the existence of a clear concavity on the topogra-

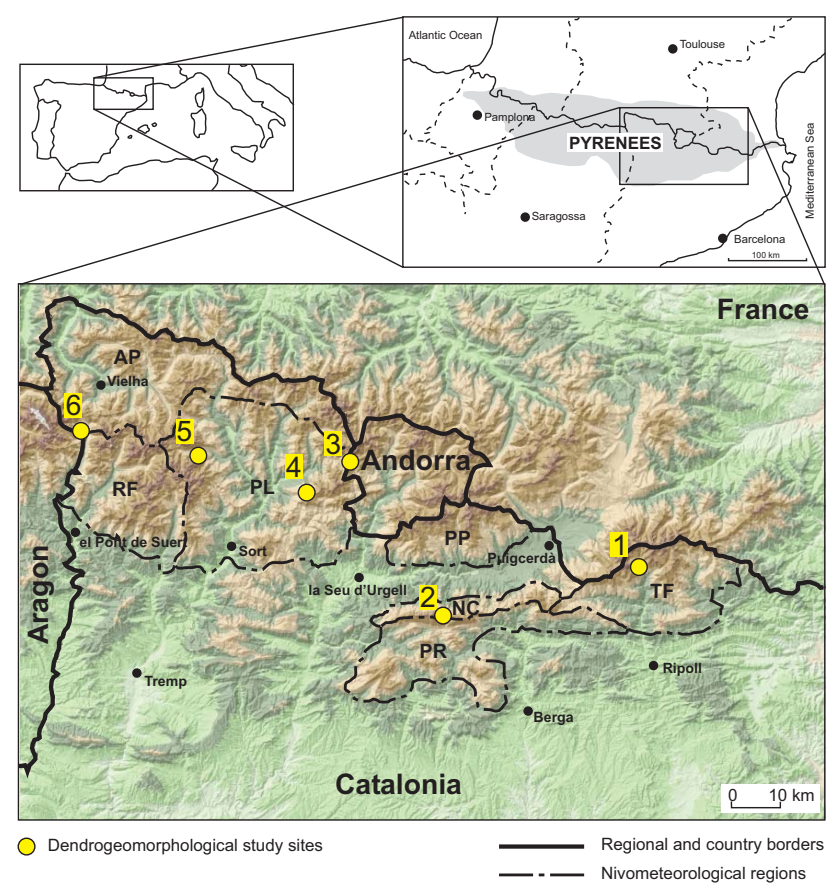

Fig. 1. Shadow relief image (ICC) of the study region, Pyrenees of Catalonia, showing nivometeorological regions used in avalanche forecasting (AP: Aran-N border of Pallaresa, RF: Ribagorçana-Vall Fosca, PL: Pallaresa, PP: Perafita-Puigpedrós, NC: N slopes of Cadí Moixeró, PR: Prepirineu, and TF: Ter-Freser) and the location of dendrogeomorphological study sites (numbered from $\mathrm{E}$ to W).

phy. Occasionally, snow avalanches can cross a dirt road in the runout.

Avalanche Path 5 (AP 5, Pui de Linya) is in the National Park of Aigüestortes and Estany (lake) de Sant Maurici in the central Pyrenees. It has a long, wide starting zone. The track and the runout have a width ranging between 50 and $75 \mathrm{~m}$. The slopes of this mountain are covered with mountain pine forest reaching $2400 \mathrm{~m}$ altitude interspersed with silver fir patches (northern slopes) and Scots pine (southeastern slopes) at lower elevations.

In Avalanche Path 6 (AP 6, Fontana) the catchment occupies a stony, glacial cirque. The track begins at the neck of the cirque and is $100-150 \mathrm{~m}$ wide. A mountain pine forest mixed with silver fir flanks the avalanche track up to $2000 \mathrm{~m}$ altitude. The runout is on top of a debris cone ending up in a main road that runs along the valley. However, most snow avalanches stop short of overrunning the road. There is a parking lot in the wide runout zone, obviously exposed to avalanche hazard. Only a few woody plants are available in the runout for the dendrogeomorphological study. 
Table 1. Study site characteristics ${ }^{\mathrm{a}}$.

\begin{tabular}{|c|c|c|c|c|c|c|c|}
\hline $\begin{array}{l}\text { Study } \\
\text { site }\end{array}$ & Toponym & $\mathrm{AP}$ & $\begin{array}{l}\text { SZ-RZ } \\
\text { elevation } \\
\text { (m a.s.1.) }\end{array}$ & $\begin{array}{l}\text { Altitudinal } \\
\text { gradient } \\
\text { (m) }\end{array}$ & Aspect & NM & Vegetation \\
\hline 1 & $\begin{array}{l}\text { Canal del Roc Roig } \\
\text { Vall de Núria }\end{array}$ & NUR127 & $2275-1775$ & 500 & ENE & $\mathrm{TF}$ & Pinus uncinata forest \\
\hline 2 & $\begin{array}{l}\text { Canal del Ticó (Llitze) } \\
\text { Serra del Cadí N }\end{array}$ & SGR452 & $2550-1675$ & 875 & $\mathrm{~N}$ & $\mathrm{NC}$ & P. uncinata forest \\
\hline 3 & $\begin{array}{l}\text { Barranc de Tor } \\
\text { Plaià }\end{array}$ & RDT122 & $2700-1900$ & 800 & $\mathrm{~S}$ & PL-AP & $\begin{array}{l}\text { Mixed } P \text {. uncinata } \text { and } \\
\text { P. sylvestris forest, } \\
\text { P. uncinata (above } 2150 \mathrm{~m} \text { a.s.1.) }\end{array}$ \\
\hline 4 & $\begin{array}{l}\text { Costa dels Meners } \\
\text { Bosc de Virós }\end{array}$ & VFR005 & $2400-2010$ & 390 & $\mathrm{~N}$ & PL & P. uncinata forest \\
\hline 5 & $\begin{array}{l}\text { Envallase } \\
\text { Pui de Linya }\end{array}$ & PEG002 & $2770-1890$ & 880 & ENE & PL & P. uncinata forest \\
\hline 6 & $\begin{array}{l}\text { Pic de Fontana } \\
\text { de Viella }\end{array}$ & RIB005 & $2580-1545$ & 1035 & $\mathrm{E}$ & RF-AP & $\begin{array}{l}\text { Mixed Fagus sylvatica and } \\
\text { Abies alba forest, } \\
\text { P. uncinata (above } 1800 \mathrm{~m} \text { a.s.1.) }\end{array}$ \\
\hline
\end{tabular}

a AP - six-digit code corresponding to specific avalanche path identification in the Avalanche Paths Map of Catalonia (ICC 1996-2006); SZ - Starting zone; RZ - Runout zone; NM - Nivometeorological region.

\section{Materials and Methods}

To achieve our objectives, the methods used in our study were as follows: 1) dendrogeomorphology to date and reconstruct past avalanches in six avalanche paths, and 2) analysis of meteorological and nivometeorological records to determine the weather conditions that could have triggered individual avalanches and widespread avalanche events.

\subsection{Dendrogeomorphological procedures}

Samples from Pinus uncinata trees were collected by utilizing dendrogeomorphological methods described by Burrows and Burrows (1976) and Shroder (1978). Care was taken to employ non-destructive methods for environmental reasons and thus, increment borers were used to extract cores ( $5 \mathrm{~mm}$ in diameter) from living trees. Cross-sections were obtained from dead trees, but these have not been used for the present work. A reference chronology with samples from old trees apparently not affected by avalanches was built at each study site. Reference chronologies were used to confirm correct datings and to exclude any atypical growth responses that could be attributed to climate or other growth disturbances. The field sampling campaigns were performed during the summers of 2003 and 2004.

Figure 2 illustrates the sampling method in AP 1, 4 and 5. Here the dendrogeomorphological study was performed by running a number of 1 to $2-m$ wide transects across the avalanche track and runout at different elevations. Whenever possible, the transects were set at a distance of $50 \mathrm{~m}$ uphill, to cover the whole avalanche trajectory from the runout up to the treeline. Scattered trees with particular external features possibly caused by snow avalanches were also sampled.

In AP 2, 3 and 6 the sampling work was less exhaustive (Fig. 2). In AP 2, only one transect across the middle track and ten selected trees in the runout zone were sampled. In AP 3, trees were sampled systematically along five $30 \mathrm{~m}$ transects in the runout-zone forest. In AP 6, selected trees were sampled at different elevations along the track.

Standard dendrochronological procedures were used to prepare and analyse the wood samples (Fritts, 1976; Stokes and Smiley, 1968). All samples were visually cross-dated.

Statistical verification was done using the computer programm COFECHA (Holmes, 1983), but visual description of ring characteristics was crucial because statistical dating tests were not successful in a large number of the avalanche path samples owing to extreme ring-width alterations.

Abrupt growth changes in ring width (release and suppression sequences that are not present in the reference chronology), reaction wood (which is ordinarily related to tree tilting) and growth cessation (due to local death of cambial cells in the case of scars) were used to date avalanche events. Regeneration as evidence of past disturbances was not employed given discrepancies in tree establishment dates. Resin ducts as indicators were also avoided because of the number of resin ducts ordinarily displayed by Pinus uncinata. Root samples were not used owing to the difficulty for crossdating them. Dead trees supply complete tree sections where 


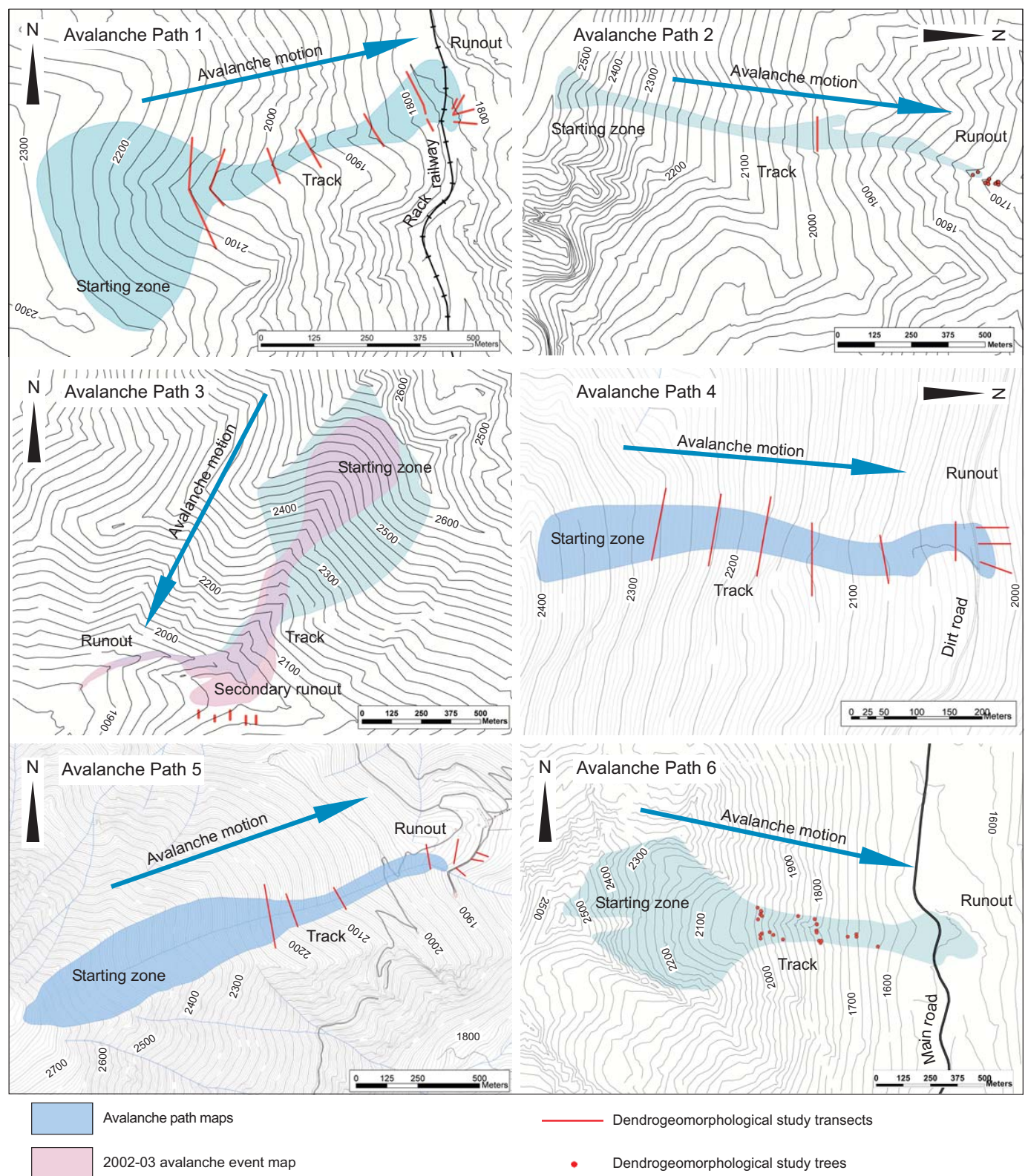

Fig. 2. Avalanche path maps (ICC) showing the sampling strategies used in each of the study sites.

ring features are more easily observed. However, as tree debris get rotten and disappear, part of the evidence is lost making comparisons between percentages of recent and past events tricky. Moreover, given that most dead trees are transported, they do not provide reliable information about event extent. For this reason, only living trees were used to infer avalanche occurrences and size on this occasion. In our research, the different tree-ring signals had equal weight in the event-response sum. Although a tree could present several tree-ring signals, it was counted only once. Finally, no attempt was done to rate avalanche intensity using the duration of tree-ring responses.
The following criteria were used to confirm the occurrence of snow avalanches by means of dendrogeomorphological analyses: 1) the absence of similar growth reactions in the reference chronology, 2) the concurrence within the same tree or among trees of a variety of tree-ring responses, 3) the spatial distribution of growth-disturbed trees in the track and in the runout, and 4) the proportion of trees with ring evidence similar to or higher than the results from documented avalanches. 
Avalanches can attain different sizes in the same avalanche path. For the purpose of this research, we have considered events reaching the runout as an indicator of most likely major avalanches. According to Schaerer (1986), avalanches that occur once in every 5 to 20 years affecting transport infrastructure and causing damage to property are typically much larger than annually observed avalanches. Therefore, in addition to the total count of trees with growth disturbances along the avalanche path, we paid particular attention to growth disturbed trees (GD trees) located in the lower track and in the runout zone. The time period considered was directly related to a lower limit of twenty trees sampled in the whole avalanche path, or ten trees sampled at the lower tract (track/runout), and in this way, it varied from one site to another (see Sect. 5.1.). In addition to this spatial consideration, to set a rough threshold for the percentage of trees needed (Index Number by Shroder, 1978) to accept the occurrence of a snow avalanche, we used the minimum value corresponding to a documented event in AP 1 (where several events had been reported) which was $16 \%$. This cut-off number was used in the densely sampled AP 1, 4 and 5. In less-exhaustively sampled paths AP 2, 3 and 6, we used a higher index of $40 \%$ after Butler et al. (1987).

\subsection{Archival data from past avalanches}

Information about past avalanche events was obtained from the Avalanche Database of Catalonia (Base de Dades d'Allaus de Catalunya, Institut Geològic de Catalunya: http://galileo.icc.es/website/cartoallaus_icc/viewer.htm? ActiveLayer=foto\&Usuari=consulta\&), which gathers data from various sources: winter monitoring, field survey, historical documentation, interviews with local people and eyewitness accounts. This was used to corroborate some of the dates yielded by our dendrogeomorphological study.

\subsection{Weather and snow conditions}

Major snow avalanches occur when critical combinations of weather and snowpack conditions arise. Once avalanche event years were determined by the dendrogeomorphological study, daily weather records were examined to find reasonable avalanche-release conditions. Owing to data availability, the analysed period was from 1971-1972 to 2003-2004. Data were obtained from manual and automatic meteorological stations of the National Meteorological Institute of Spain (INM), the Meteorological Survey of Catalonia (SMC), and the Nivometeorological Observers Network (NIVOBS) of the Cartographic Institute of Catalonia (ICC). The NIVOBS has carried out winter surveys to report snowpack conditions and avalanche events since 1986. These observations became daily after 1996.

Attention was focused on the meteorological conditions responsible for unstable structures of the snowpack (Armstrong, 1976). The nivometeorological parameters and con- ditions that play a role in critical avalanche situations in the SE Pyrenees (García et al., 2006) are as follows: fresh snow accumulation in $72 \mathrm{~h}$, rain precipitation over $2200 \mathrm{~m}$ altitude, wind speed exceeding $15 \mathrm{~m} \mathrm{~s}^{-1}$ and sequences of days with isozero above $3000 \mathrm{~m}$. In addition, conditions that generate weak layers in the snowpack (faceted grains, depth hoar and surface hoar) were also detected, since not all major avalanches are linked to intense precipitation. Weak layers overloaded by thick wind slabs and by wet slabs in melting situations generate major avalanches, as well. Thus, we looked for weather conditions such as sequences of days of high snow irradiation and sequences of days with daily maximum temperature below $0^{\circ} \mathrm{C}$. When the most predictable meteorological and nivometeorological avalanche-release conditions were identified, synoptic atmospheric situations were selected from the NCEP-NCAR ${ }^{1}$ reanalysis data (Kalnay et al., 1996) by using maps at sea level pressure, at $850 \mathrm{hPa}$, and at $500 \mathrm{hPa}$.

\section{Results}

\subsection{Past snow avalanches}

Results refer to Pinus uncinata exclusively, the most abundant tree species in all the study sites. The length of the study period varied within each site, but as a rule, the youngest tree samples covered the last 10 years and the oldest, from 180 to 250 years (Table 2). No attempt was done to date the age of the trees. Roughly, half of the trees were older than 40 years at all sites, and older than 90 years in AP 3 and 4. As has been pointed out in Sect. 4.1, the sample methodology in AP 1, 4 and 5 was more intensive than in AP 2, 3 and 6.

\subsubsection{Avalanche paths 1,4 and 5}

The occurrence of large-scale snow avalanches was widespread in the Pyrenean range during the winter of 1995-1996. Many of these events were regarded as major avalanches damaging vast tracts of forest. Because major avalanches in paths 1,4 , and 5 were documented during this winter they were chosen to find out whether similar events took place in the past. The event-response histograms for AP 1, 4 and 5 are shown in Fig. 3. The bar corresponding to the 1995-1996 events clearly stands out in these sites. The proportion of trees showing tree-ring signals was $32 \%$ at AP 1 , $53 \%$ at AP 4 , and $57 \%$ at AP 5 of the total number of sampled trees (131, 92, and 129, respectively).

In AP 1 major avalanches damaged the rack railway in the winters of 1971-1972, 1985-1986 and 1995-1996. These seasons hold the highest proportion of GD trees along the track and some trees show evidence at the runout as well (see corresponding histogram in Fig. 3). Although evidence

\footnotetext{
${ }^{1}$ National Centers for Environmental Prediction and National Center for Atmospheric Research, USA
} 
Table 2. Trees used for dendrochronological analyses.

\begin{tabular}{cccc}
\hline Study site & Sampled trees & Age range & Age $\bar{X} \pm 1 S D$ \\
\hline 1 & 131 & $10-219$ & $49.7 \pm 35.1$ \\
2 & 36 & $18-188$ & $53.0 \pm 31.7$ \\
3 & 34 & $10-181$ & $81.7 \pm 37.2$ \\
4 & 92 & $14-196$ & $95.7 \pm 43.3$ \\
5 & 129 & $10-250$ & $43.7 \pm 30.5$ \\
6 & 26 & $14-185$ & $57.3 \pm 38.6$ \\
\hline
\end{tabular}

for events is also high in 1973-1974, 1981-1982 and 19901991, it is likely that snow avalanches in these seasons did not reach the runout, but stopped some way up the track. In this avalanche path, we were able to enlarge the span period owing to the unexpected finding of a picture taken in 1930 portraying an avalanche deposit at the runout, which corroborated the tree-ring evidence of a high magnitude avalanche in 1929-1930 (Fig. 4).

In AP 4 an avalanche in 1996 swept through a stretch of mature forest. As shown in Fig. 3 a high proportion of GD trees in 1995-1996 was detected in the upper portions of the path. Seven trees in the runout zone of AP 4 provided evidence of this same avalanche event as well. Dendrogeomorphological results showed no similar event for more than a century. A high proportion of GD trees in 1878-1979, 1958-1959, 1963-1964 and 1990-1991 may correspond to avalanche events that reached the middle track.

In AP 5, many trees were destroyed in the 1995-1996 season. The dendrogeomorphological analysis corroborated this event and revealed another major avalanche that took place in 1971-1972. A high amount of evidence was found for 1973-1974 at the runout as well (13 trees), but although the $16 \%$ threshold was surpassed, there was little evidence in the track (5 trees) (see Sect. 6.1). A smaller event was dated in 1978-1979.

\subsubsection{Avalanche paths 2,3 and 6}

The event response histograms of the less exhaustively sampled avalanche paths are presented in Fig. 5. In AP 2, according to an eyewitness, an avalanche released in 2003 and brought down numerous trees. Only samples from ten trees were collected in the narrow runout and from 26 along a transect at the middle track. Here five events reaching the runout were dated by dendrochronology: 1968-1969, 1971-1972, 1981-1982, 1995-1996 and 2002-2003. There was no evidence of the avalanche in 1995-1996 at this site previous to the analysis.

In AP 3, winter surveys reported two major avalanches in 1996 and in 2003. The 1995-1996 event followed the mountain torrent, but the event in 2002-2003 ran into the secondary runout (Fig. 2) breaking and uprooting a few large trees ( $>70 \mathrm{~cm}$ diameter at breast height). The sampling design was focused on this secondary runout area linked to rare high magnitude events. Here 39 trees were sampled in the runout. Dendrogeomorphology confirmed the event in 2002-2003. It also confirmed that the event in 1995-1996 had not reached this secondary runout. Tree-ring evidence found in 1909, 1927 and 1935 (three, four and three trees, respectively) could not be evaluated, since no samples were collected in the avalanche track.

In AP 6, dendrogeomorphological evidence for events in 1985-1986, 1993-1994, 1995-1996 and 2002-2003 was obtained, but no living trees were sampled in the runout. For this reason we could not verify the extent of these avalanches. Interestingly, a reported avalanche in 2003-2004, which engulfed a car driving along the road in the runout, was not detected. In this study site, the dendrogeomorphological analyses were limited by the scarcity of trees and woody plants in the runout.

Figure 6 summarizes all the dated snow-avalanche events in the six avalanche paths of the study.

\subsection{Meteorological and nivometeorological factors associated with major avalanche winters}

The results of the research in meteorological and nivometeorological records for the period between 1971-1972 and 2003-2004 are shown in Fig. 7. Compared with the other avalanche seasons, in 1971-1972, 1995-1996 and 20022003 winters, a higher number of nivometeorological regions were affected by avalanches (four, seven and three, respectively).

\subsubsection{Major avalanche season 1971-1972}

In 1971-1972 an extensive avalanche episode took place affecting a large area that comprised four nivometeorological regions. On 16-17 January, extensive but moderate snowfalls were recorded across the Pyrenees $\left(40-601 \mathrm{~m}^{-2}\right.$ of snowwater equivalent above $2000 \mathrm{~m}$, but less in the valley bottoms). The synoptic atmospheric situation consisted in a deep trough crossing the range from west to east. Southern winds in cyclonic circulation blew over the Pyrenees, which favoured the precipitation by uplift effect due to the configuration of the main valleys. Taking into account the distribution of the thermal isolines at $850 \mathrm{hPa}$ topography, the snow level was assumed to be above $1600-1700 \mathrm{~m}$ above sea level (a.s.l.) in the beginning, but descending as time passed. Under these conditions, fresh snow might have been wet and dense. The weather of the days preceding the snowfall was characterized by the passing of warm and cold frontal systems from the Atlantic Ocean. In these circumstances precipitations are usually scarce, but in the Pyrenees between 1500 and $2000 \mathrm{~m}$, rain and snow alternate. These conditions favour the formation of weak faceted grains above thin crusts and as it is observed in a variety of snow climates avalanches 

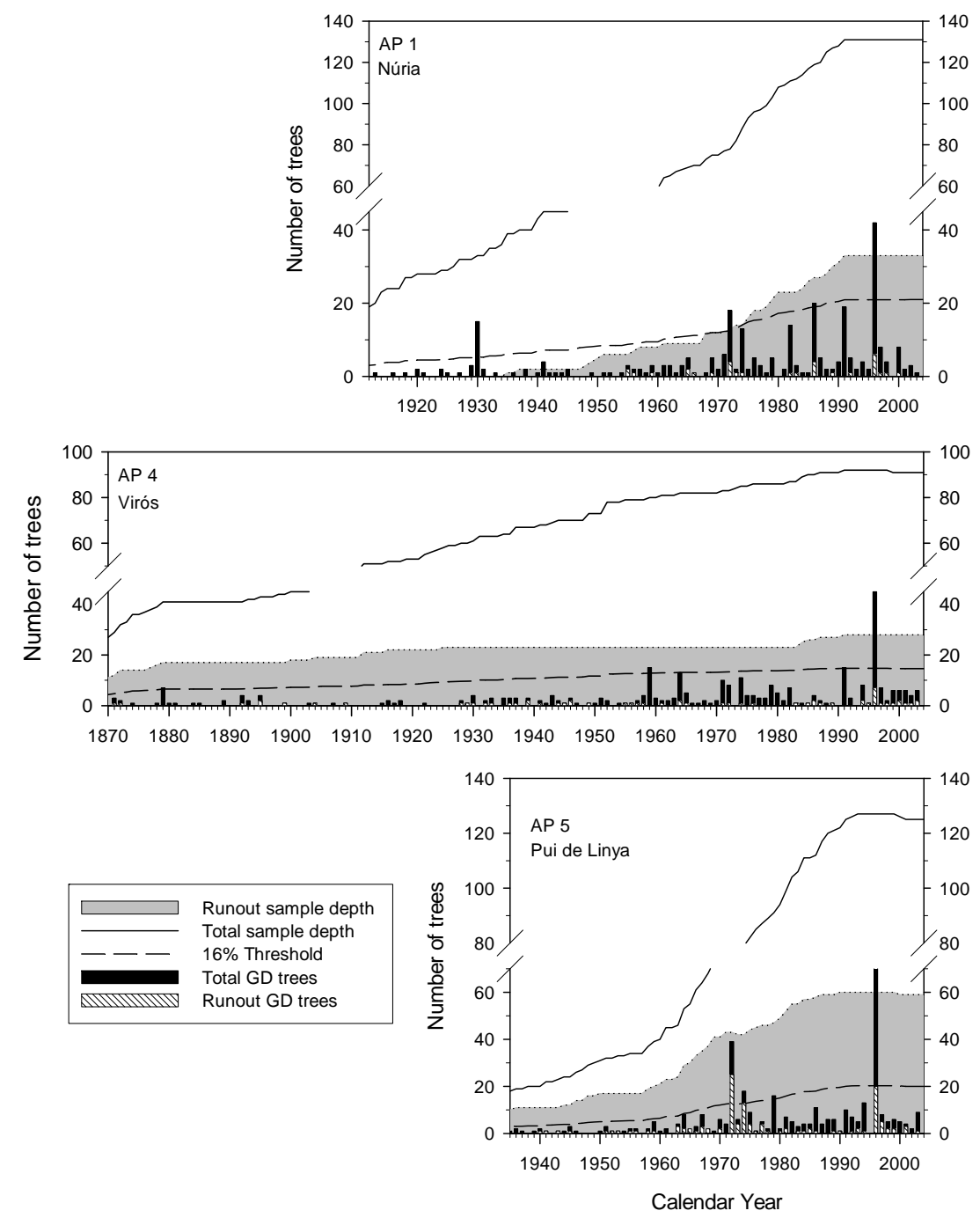

Fig. 3. Event response histograms for paths AP 1, AP 4 and AP 5. The length of the time spanned coincides with a minimum sample size of 20 trees.

may release as a result of that unstable snowpack structure (Jamieson, 2006). In addition on 18 January a cut-off low was identifiable both in the sea level surface map and in the $500 \mathrm{hPa}$ map over the Mediterranean Sea. This situation generally generates strong northern winds over the TF region, resulting in the formation of thick wind slabs on south-oriented slopes. On 18 January, a large avalanche released from the south-oriented slope that damaged the rack railway in Nuria Valley at AP 1 (TF region).

\subsubsection{Major avalanche season 2002-2003}

During the winter 2002-2003, two avalanche episodes that affected three nivometeorological regions were reported (AN, PL and RV). In the first episode, from 26-30 January 2003, a north advection produced heavy snowfalls during $96 \mathrm{~h}$ accounting for more than two meters of new fallen snow at $2200 \mathrm{~m}$ a.s.1. Much of the snow accumulation was due in part to wind drifting. Data was difficult to measure because of the strong winds (around $90 \mathrm{~km} \mathrm{~h}^{-1}$ ) at high-altitude weather stations. However, the total amount of fresh snow that accumulated in the valley floors, which were sheltered from the strong winds corresponds to a return period of 30 years and draws attention to the severity of the event (Esteban et al., 2005). Following this storm, a total of 39 major avalanches released in three regions (AN, PL and RV). Snow profiles done close to the fracture line showed the formation of thick wind slabs on lee slopes with densities ranging from $140-180 \mathrm{~kg} \mathrm{~m}^{-3}$. Ram profiles indicated that below these wind slabs were thin crusts alternating with weak interfaces. A strong thermal gradient in the contact between the crust and the new fallen snow likely favoured the formation of a weak interface propitious to avalanche release. 


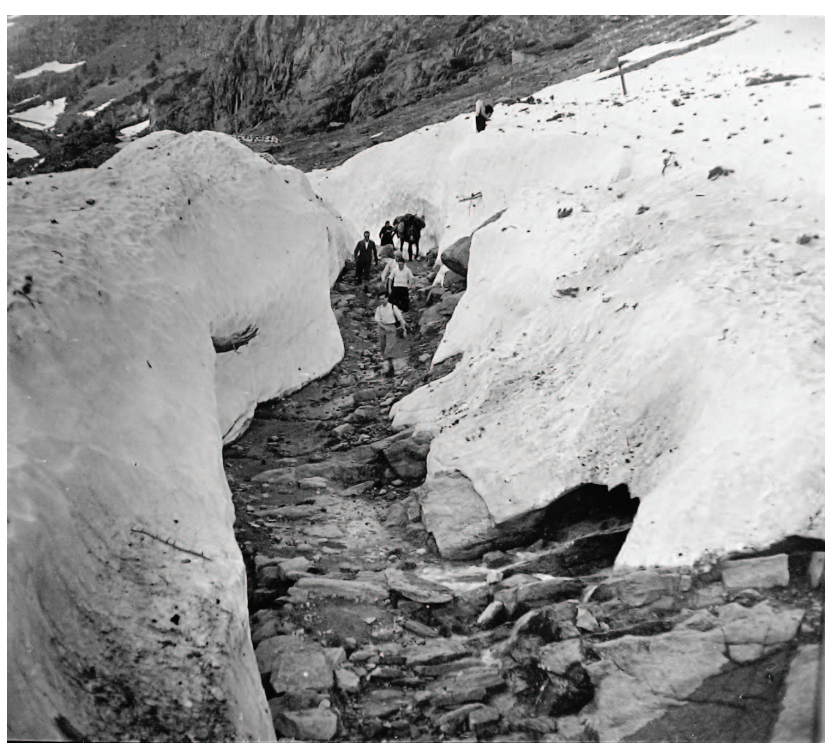

Fig. 4. Old photograph showing an avalanche event in AP 1 that occurred in 1929-1930. The people are walking through the snow deposition in the runout zone. Note the broken trees protruding from the snow. From the picture, the deposition was more or less four meters high (in 1995-1996, the deposition was two meters) (with permission of Centre Excursionista de Catalunya archive; author, Albert Oliveras).
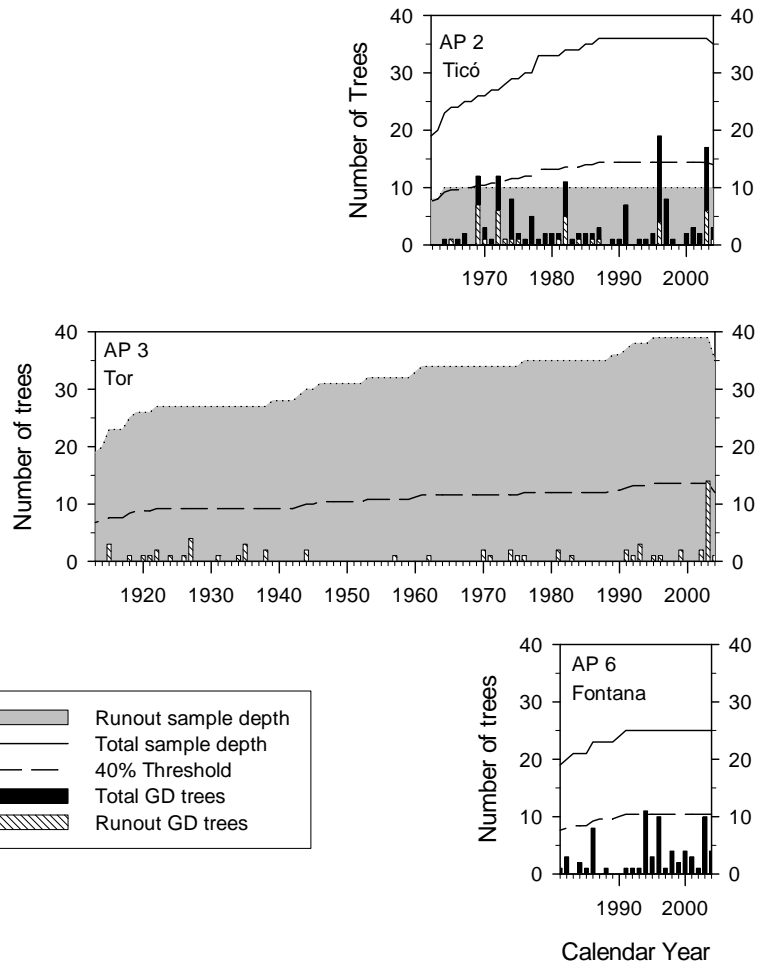

Fig. 5. Event response histograms for avalanche paths AP 2, AP 3, and AP 6.
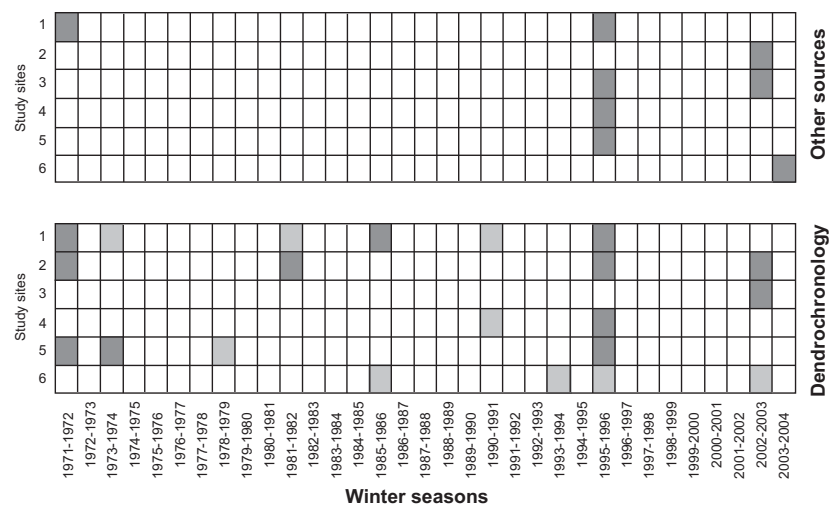

Fig. 6. Dates of snow-avalanche events from 1971-1972 to 2003 2004 in the studied avalanche paths. The upper chart shows the dates obtained from the Avalanche Database of Catalonia. The lower chart depicts the dates obtained by dendrochronology. Dark grey squares correspond to major avalanches and light grey to smaller avalanche events where there is no tree-ring evidence at the runout.

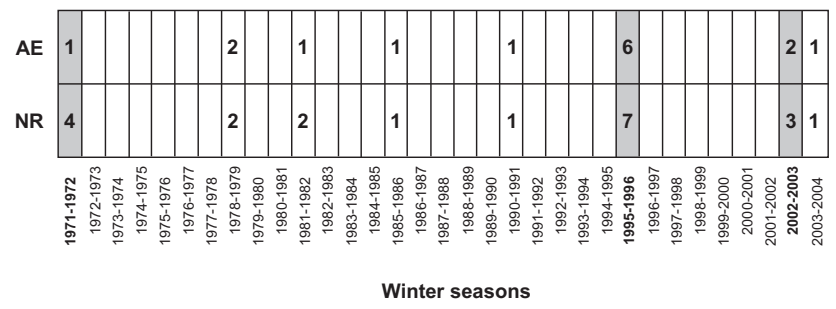

Fig. 7. Potential avalanche episodes and nivometeorological regions affected from 1971-1972 to 2003-2004. Avalanche activity was particularly high in winters 1971-1972, 1995-1996, and 20022003 (AE-number of avalanche episodes, NR-affected nivometeorological regions).

The second episode took place from 26-28 February. As in the 1971-1972 episode, a deep trough crossed the Pyrenees from west to east, but on this occasion, a small vortex with a humid, strong south-eastern flow coming from the Mediterranean Sea towards the southern side of the Pyrenees was generated. Winds blew from the south at 40$90 \mathrm{~km} \mathrm{~h}^{-1}$. The total fresh snow accumulation ranged between $40-100 \mathrm{~cm}$ at $2200 \mathrm{~m}$ in $72 \mathrm{~h}$. The new snow was very wet and dense and largely comprised of rimed crystals. Large avalanches released from 27-28 February mainly on northoriented slopes.

\subsubsection{Major avalanche season 1995-1996}

The 1995-1996 winter was unusual because of the large number and regional extent of avalanche episodes (six in total). In addition, these episodes were triggered by different meteorological conditions (García et al., 2006). All the seven nivometeorological regions were affected by major avalanches in the winter of 1995-1996. Indeed, some 
regions such as the western RF and the eastern TF were affected by major avalanches several times in the same winter (three times each). Figure 8 provides a schematic overview of the nivometeorological regions affected by the diverse atmospheric conditions.

The episode of December 1995 corresponded to an east advection. It was explained by a blocking high pressures situation at $500 \mathrm{hPa}$ over Central Europe and a cut-off low centred over the southwest of the Iberian Peninsula. A warm and very humid Mediterranean flow on surface penetrated from the east affecting the regions closest to the Mediterranean Sea, and also distant regions such as south-facing RF.

The most intense major avalanche episode took place at the end of January 1996 as a result of a southwestern synoptic situation. A number of large, powder snow avalanches over four nivometeorological regions were triggered shortly after snowfall (Fig. 8). A deep low pressure was located over the northwestern coast of the Iberian Peninsula. From surface to upper atmospheric levels south and southwesterly winds prevailed bringing warm and humid air from the Atlantic and the Mediterranean to the lower levels in the Pyrenees. High instability was attributed to a deep cold core at $500 \mathrm{hPa}$ level. In the PR region, a precipitation gauge at the Port del Comte nivometeorological station recorded a maximum of $2201 \mathrm{~m}^{-2}$ of snow water equivalent in $24 \mathrm{~h}$, and snowfall exceeding $1501 \mathrm{~m}^{-2}$ was recorded in several other nivometeorological regions. These extreme values were largely atributted to convective cell growth. This means a Gümbel return period (Gumbel, 1958) for a snowfall slightly exceeding 100 years in the PR region. A return period is an estimate of the expected interval of time between events; note that it means that an event will not happen regularly in the given interval of time, but it has been observed to occur in this interval. As shown by Esteban et al. (2005), heavy snowfall including torrential rains affect the southern side of the Pyrenees in such a synoptic circulation pattern.

From 6 through 9 February 1996 another large avalanche episode occurred. The storm was a result of typical northwestern advection characterized by both warm and cold fronts passing over the Pyrenees and giving rise to high and low snow levels and intermittent precipitation. Intense drifting that occurred during the storm made it difficult to determine the amount of precipitation. However, the maximum amount of new snow above $2000 \mathrm{~m}$ a.s.l. reached 100 to $140 \mathrm{~cm}$ after $72 \mathrm{~h}$ of snowfall in the AP region. Although some regions uncommonly experience snowfall in the northwestern advection regime, extreme avalanches do occur under this synoptic pattern where snowfall is abundant. It may also be suggested that extreme avalanches took place in regions where new snowfall amounts were moderate owing to snow accumulated/transported by the wind from the preceding episode (21-24 January). Large amounts of drifted snow exceeding four to five meters in depth were measured in the avalanche starting zones on lee slopes. The new snow was mainly comprised of small, low density fragments that drift easily. Fresh wind slabs overloaded southern lee slopes and eventually released.

The fourth episode was caused by a storm with strong winds from the north on 22 February. The Azores high pressures were extended in a north-south axis over the Atlantic Ocean, while a deep low pressure was located on the Baltic Sea-Italian Peninsula axis in a typical configuration. This pattern pumps either an arctic or a maritime polar air mass over the Pyrenees, and generates very low temperatures $\left(-15\right.$ to $-20^{\circ} \mathrm{C}$ at $2200 \mathrm{~m}$ a.s.l.), intense snowfalls, strong winds and very active snow drift processes which can result in avalanche releases.

The fifth episode occurred on 14 March and it corresponded to a trough passing. In this pattern, atmospheric circulation is characterized by a long trough at $500 \mathrm{hPa}$ exhibiting an oblique NW-SE axis, caused by the Siberian high pressure over Europe which diverts troughs to the Mediterranean basin. Normally, this yields a small low at surface atmospheric level over the Mediterranean Sea. A humid, maritime flow on surface produces heavy precipitation in the regions closest to the Mediterranean Sea. Instability is high due to the contrast between cold air at $500 \mathrm{hPa}$ and a relatively warm air mass at low atmospheric levels. The snowpack usually contains weak layers with depth hoar and faceted grains before fresh snow arrives, since low temperatures and strong irradiation prevail below the Siberian high pressures influence.

The last episode took place from 22 through 24 March and it was associated to melting processes. A ridge from the subtropical anticyclonic belt spread to the north over the Western Mediterranean Sea. Usually, when this occurs, a warm advection at low atmospheric levels $(850,700 \mathrm{hPa})$ reaches the Pyrenees. The snow cover suffered sudden melting processes and major avalanches descended while the inner layers still contained cold, persistent grains.

\section{Discussion}

\subsection{Dendrogeomorphology}

Our dendrochronological analyses corroborated most of the documented dates and yielded other avalanche dates that had not been recorded hitherto in the six avalanche paths we sampled (Fig. 6). By examining the spatial distribution of GD trees within each path, we verified whether avalanches had reached the runout or had most likely stopped higher in the track. The number of detected major avalanche events increased from 1971-1972 to 2003-2004 from 8 to 14. These occurred in a total of nine winter seasons. Twelve minor events were also detected. As indicated by Hebertson and Jenkins (2003), major avalanche episodes are expected to affect a large number of paths. In our study, regional-scale weather patterns during the winters of 1971-1972, 19951996, and 2002-2003 resulted in avalanches affecting at least 


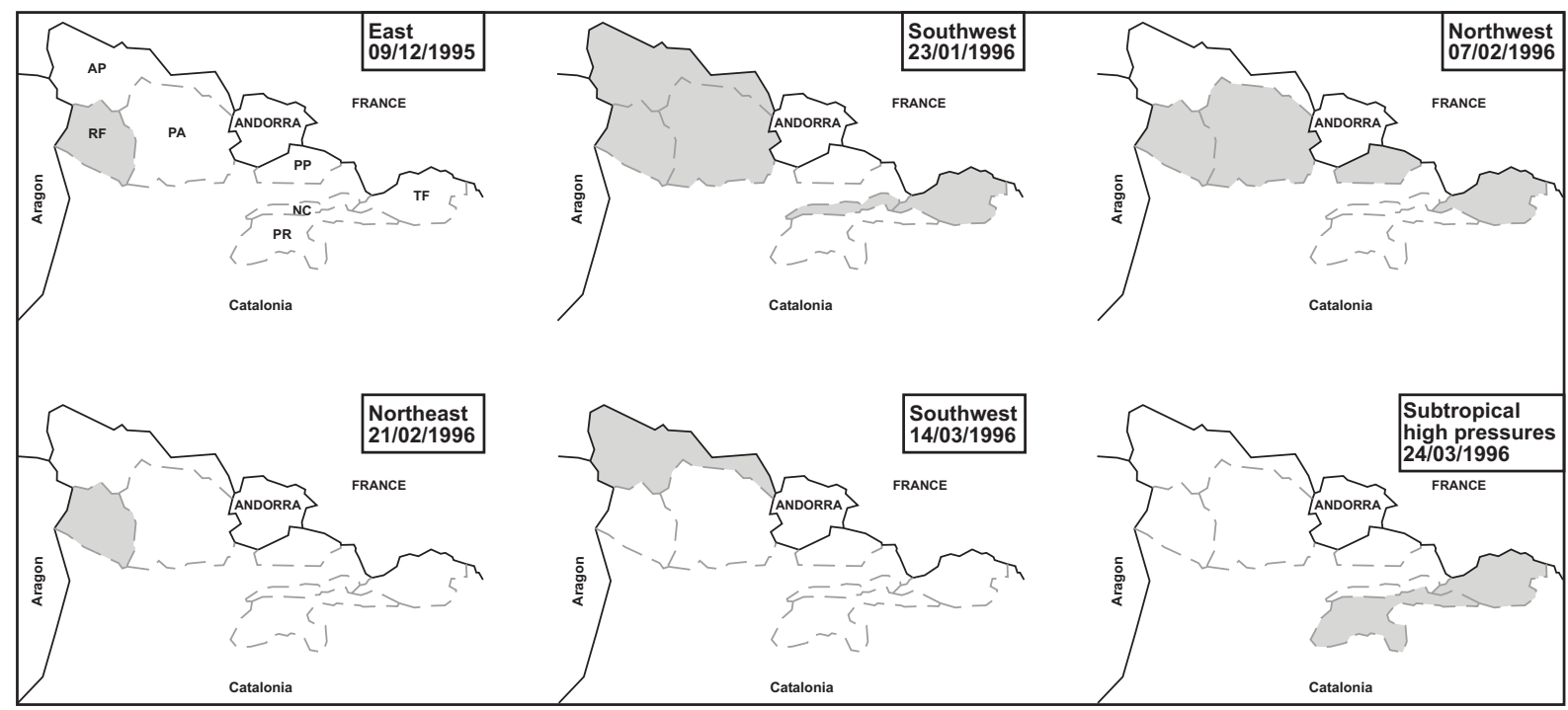

Fig. 8. Atmospheric conditions of potential avalanche episodes and affected nivoclimatic regions in 1995-1996 winter in the SE Pyrenees.

three paths each. Snow avalanches occurred in all six paths in 1995-1996 suggesting the severity of this winter.

The sampling design in AP 1, 4 and 5, provided the most reliable results on avalanche dating, and allowed the extent of successive events to be more accurately mapped, or existing maps expanded. This is an improvement over conventional avalanche mapping techniques, particularly in paths where visual indications of forest damage are no longer apparent. For example, in AP 5, dendrogeomorphology revealed that a high-magnitude avalanche in 1971-1972 exceeded the runout by a considerable distance (Fig. 9). Consequently, the runout map was increased by $200 \mathrm{~m}$.

The less exhaustive sampling carried out in paths AP 2, 3, and 6 did not provide interesting results in terms of time period and extent of avalanche events, but rather illustrated the limitations of different sampling strategies. As long as these limitations are realized however, results can still be robust. For example, in the narrow AP 2 path we discovered that avalanches are very frequent, but we conjecture that event size or severity could vary according to avalanche width and not to length. This could not be evaluated by sampling trees only in the middle track and in the runout. Further research to settle this presumption should include sampling along transects at intermediate elevations. In AP 3, where sampling was done in the runout, the evidence detected for 1909, 1927 and 1935 could not be validated with samples from the track. This hampered the interpretation of potential events of similar magnitude such as the exceptional avalanche occurred in 2002-2003.

In AP 6, an avalanche documented in 2003-2004 was not detected by dendrogeomorphological means. This could be due to the natural scarcity of trees in the runout, or perhaps to previous avalanches that occurred in 1995-1996 and 20022003 and destroyed the trees along the track.
A similar circumstance could have happened in AP 5 for the 1973-1974 event. A major event in 1971-1972 could have removed the majority of trees in the avalanche path reducing the possibility of recording a subsequent event. This previous large event could also have facilitated the release of a later event a short time after. The removal of a large number of trees that typically serve as snowpack anchors results in a smoother path. This can contribute to greater avalanche frequency even in regions where nivometeorological conditions are not especially propitious. Further support for this idea was found at AP 1, where two major avalanches were registered in the same winter, 1995-1996 (see Molina et al., 2004). In this same way, Germain et al. (2005) reported evidence of increased avalanche activity in paths denuded by forest fires and logging.

Events that had been documented in 1995-1996 showed high index numbers (from 32 to $57 \%$ of GD trees), but these were extreme events. The documented event in 1985-1986 at AP 1 displayed a lower $16 \%$. This percentage was used in the present work as a rough threshold to decide avalanche occurrences. In our opinion, low indexes should be used only in the case of densely sampled avalanche paths (such as AP 1, 4 and 5). The prevailing rule in this present research was not only to consider the spatial distribution of evidence, stressing the importance of the runout GD trees, but also the importance of track sample replicates. In the case of poorly sampled avalanche paths (AP 2, 3 and 6) deciding thresholds were more restrictive and, apart from the runout consideration, more than $40 \%$ GD trees were required to assess avalanche occurrence. The question is how to develop complete tree-ring chronologies in the event an avalanche destroys all the trees in a path and consequently most evidence. Carrara (1979) first posed this question suggesting that avalanches which were not powerful enough to 


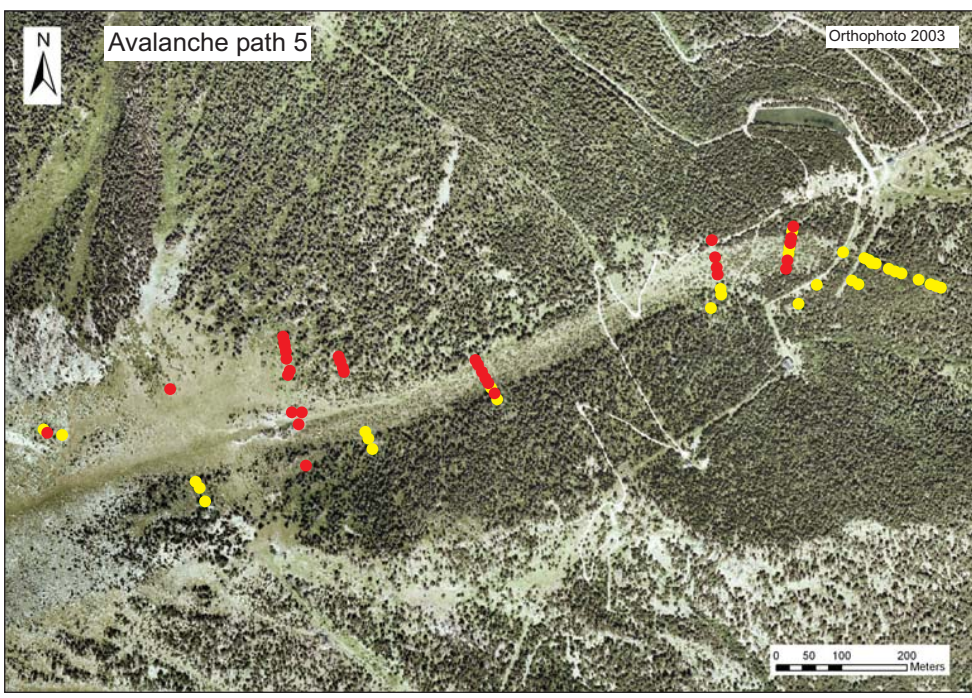

Trees showing dendrochronological evidence of 1971-1972 snow avalanche

- Trees showing dendrochronological evidence of 1995-1996 snow avalanche
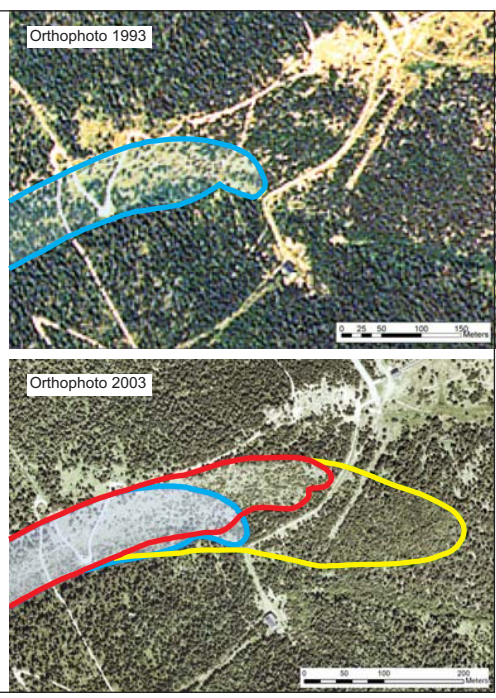

Published avalanche path map 1971-1972 snow avalanche 1995-1996 snow avalanche

Fig. 9. Dendrogeomorphological mapping. The avalanche path map in AP 5 was improved using dendrogeomorphology. The 1971-1972 major event (not detected by conventional field surveys) allowed us to extend $200 \mathrm{~m}$ the vulnerable area in the runout.

destroy trees, but instead only damage them, record their occurrence in the sequence of annual rings. Evidence of more destructive events can be lost because dead trees disappear. On the other hand, avalanche events do not always result in tree ring responses in trees as was observed in 2003-2004 documented event in AP 6. For all the above reasons, expert criteria is still compulsory to obtain reliable results, particularly in the case of sparsely forested paths, or when attempting to date old events. Experienced dendrogeomorphologists sometimes need only one tree to assess the occurrence of an avalanche (G. Furdada, personal communication, 2002). Nevertheless, information provided by means of dendrogeomorphological methods is the most reliable compared to other approaches such as vegetation evidence or enquiries to old people. The dates yielded by trees have annual resolution, are absolutety dated and have spatial positioning. Thus, by means of an appropriate sampling, dendrogeomorphology can provide information about the extent and occurrence of past avalanche events.

\subsection{Nivometeorology}

From a nivometeorological point of view, it should be noted that the three major avalanche seasons (1971-1972, 19951996 and 2002-2003) were characterised by a wide variety of atmospheric situations that released major avalanches. Nine avalanche release episodes corresponded to six different synoptic patterns. The major avalanche episodes were correlated with synoptic patterns in the Eastern Pyrenees from 19851986 to 2005-2006. Synoptic patterns leading to major avalanches were found out. They were northwestern advection, trough passing pattern, eastern advection, southwestern advection, low centered pattern and subtropical ridge pattern. Compared with nearby mountain ranges like the French Alps, the Eastern Pyrenees exhibit a wider variety of synoptic patterns releasing major snow avalanches. Accordingly, weather patterns resulting in some avalanche episodes were more localized, i.e. one nivometeorological region affected during the second episode of 2002-2003, and others resulted in a wide spatial extent of releases, i.e. four regions affected during the episode of 1971-1972. In this study, the southwestern synoptic pattern was most common during the three winters with major avalanche occurrence and was the synoptic pattern that affected most nivometeorological regions (three in average).

As shown by Beniston et al. (1996), the evolution of the main meteorological parameters such as temperature, precipitation and winds is conditioned by the North Atlantic Oscillation index (NAOi) in mountain ranges such as the Alps. The correlation between winter precipitation and NAOi has been investigated in the Pyrenees by Martín-Vide et al. (1999) and Esteban et al. (2001). Both their results show a negative correlation. Accordingly, in this study the three major avalanche winters of 1971-1972, 19951996 and 2002-2003 were correlated with the variation of NAO (Climatic Research Unit, University of East Anglia: http://www.cru.uea.ac.uk). These three winters had negative NAOi anomalies (standardized NAOi values for the reference period series 1961-1990 as follows: -0.13 for 1971-1972, -2.23 for $1995-1996$ and -0.09 for 2002-2003). Hence, more major avalanche episodes should be investigated in order to verify the correlation between major avalanches and NAOi. 


\section{Conclusions}

In view of these results, the winter of 1995-1996 was most extraordinary with respect to the occurrence of major avalanche events in recent decades in the SE Pyrenees. The combination of a regional dendrogeomorphological study and meteorological and nivometeorological analyses of weather records allowed us to determine whether avalanches had been the result of a generalised nivometeorological situation or whether weather conditions for avalanche release were more localized.

This study supports the assertion that where historic snow avalanche records are scarce, dendrogeomorphological methods can be used to detect past avalanche events improving the reliability of data used to determine critical parameters such as avalanche frequency and extent. This study also tested several sampling designs. From this information it was determined that sampling a high number of trees along numerous transects provides the most reliable methods to accurately date the highest number of past avalanche events per site, and to allow avalanche size comparisons as well.

As was demonstrated by the dendrogeomorphological analyses at AP 5, extreme runout distances can greatly exceed mapped distances. For land-use planning, the identification of the area in danger is of paramount importance. In hazard zoning, dendrogeomorphological mapping should be used where woody plants are available. Dendrogeomorphology is the only tool which can render evidence of the extent of past events when other sources are missing.

Acknowledgements. Financial support was provided by the Spanish Ministry of Technology and Education (project REN200202768/RIES), the European funding agency FEDER and the Autonomous Organism of National Parks from the Environmental Ministry (project reference number: 11/2003). This research was a collaboration between the Cartographic Institute of Catalonia, the University of Barcelona, the Meteorological Survey of Catalonia, and the General Council of Aran. We are grateful to: Jordi Cirés, Daniel Xifre de la Prada, Enric Batllori, Montse Ribas, Octavi Planells, Meritxell Orti, Jordi Gavaldà, Yolanda Cara, Jordi Marturià, and Verònica Vidal who helped in the different stages of this study. The following organisms facilitated the development of the field work: Vall de Núria, Parc Nacional d'Aigüestortes i Estany de Sant Maurici, Parc Natural del Cadí-Moixeró, Parc Natural de 1'Alt Pirineu and the local forest offices of the Environment and Housing Department of the Government of Catalonia. The authors are also grateful to the editor Michelle Bollschweiler, and the two anonymous referees for their suggestions which substantially improved the manuscript.

Edited by: M. Bollschweiler

Reviewed by: two anonymous referees

\section{References}

Armstrong, R. L. and Ives, J. D.: Avalanche release and snow characteristics, Occasional Paper, Institute of Arctic and Alpine Research, Boulder, Colorado, 19, 256 pp., 1976.

Beniston, M. and Rebetez, M.: Regional behaviour of minimum temperatures in Switzerland for the period 1979-1993, Theor. Appl. Climatol., Springer-Verlag, 53, 231-243, 1996.

Burrows, C. J. and Burrows, V. L.: Procedures for the study of snow avalanche chronology using the growth layers of woody plants, Occasional Paper, Institute of Arctic and Alpine Research, Boulder, Colorado, 23, 54 pp., 1976.

Butler, D. R.: Snow avalanche path terrain and vegetation, Glacier National Park, Montana, Arctic Alpine Res., 11(1), 17-32, 1979.

Butler, D. R., Malanson, G. P., and Oelfke, J. G.: Tree-ring analysis and natural hazard chronologies: minimum sample sizes and index values, Prof. Geogr., 39(1), 41-47, 1987.

Butler, D. R. and Sawyer, C. F.: Dendrogeomorphology and highmagnitude snow avalanches: a review and case study, Nat. Hazards Earth Syst. Sci., 8, 303-309, 2008,

http://www.nat-hazards-earth-syst-sci.net/8/303/2008/.

Carrara, P. E.: The determination of snow avalanche frequency through tree-ring analysis and historical records at Ophir, Colorado, Geol. Soc. Am. Bull. Part 1, 90, 773-780, 1979.

Carreras, J., Carrillo, E., Masalles, R., Ninot, J., Soriano, I., and Vigo, J.: Delimitation of the supra-forest zone in the catalan Pyrenees, Bulletin de la Societé linnéenne de Provence, 47, 27 36, 1996.

Casteller, A., Stöckli, V., Villalba, R., and Mayer, A. C.: An evaluation of dendrochronological indicators of snow avalanches in the Swiss Alps, Arct. Antarct. Alp. Res., 39(2), 218-228, 2007.

Dubé, S., Filion, L., and Hétu, B.: Tree-ring reconstruction of high-magnitude snow-avalanches in the northern Gaspé Peninsula, Québec, Canada, Arct. Antarct. Alp. Res., 36(4), 555-564, 2004.

Esteban, P., Jones, P. D., Martín-Vide, J., and Mases, M.: Atmospheric circulation patterns related to heavy snowfall days in Andorra, Pyrenees, Int. J. Climatol., 25, 319-329, 2005.

Esteban, P., Soler, X., Prohom, M., and Planchon, O.: El índice NAO y la distribución de la precipitación. Efecto del relieve a escala local: los Pirineos orientales, El Agua y el Clima, 594 pp., 2001.

Fritts, H. C.: Tree Rings and Climate, Laboratoy of Tree-Ring Research, University of Arizona, Tucson, USA, 553 pp., 1976.

Furdada, G.: Estudi de les allaus al Pirineu occidental de Catalunya: predicció espacial i aplicacions de la cartografia, published Ph.D. thesis, Ediciones Geoforma, Logroño, 315 pp., 1996.

García, C., Martí, G., García, A., Muntán, E., Oller, P., and Esteban, P.: Weather and snowpack conditions of major avalanches in the Catalan Pyrenees, Proceedings of the Alpine Snow Workshop, Munich, 49-56, 2006.

Germain, D., Filion, L., and Hétu, B.: Snow avalanche activity after fire and logging disturbances, northern Gaspé Peninsula, Quebec, Canada, Can. J. Earth Sci., 42, 2103-2116, 2005.

Gumbel, E. J.: Statistics of extremes, Columbia University Press, New York, 375 pp. 1958.

Hebertson, E. G. and Jenkins, M. J.: Historic climate factors associated with major avalanche years on the Wasatch Plateau, Utah, Cold Reg. Sci. Technol., 37, 315-332, 2003.

Holmes, R. L.: Computer-assisted quality control in tree-ring dating 
and measurement, Tree-Ring Bull., 43(1), 69-78, 1983.

Kalnay, E., Kanamitsu, M., Kistler, R., Collins, W., Deaven, D., Gandin, L., Iredell, M., Saha, S., White, G., Woollen, J., Zhu, Y., Leetmaa, A., Reynolds, R., Chelliah, M., Ebisuzaki, W., Higgins, W., Janowiak, J., Mo, K. C., Ropelewski, C., Wang, J., Jenne, R., and Joseph, D.: The NCEP/NCAR 40-year reanalysis project, B. Am. Meteorol. Soc., 77, 437-471, 1996.

Martín-Vide, J., Barriendos, M., Peña, J. C., Raso, J. M., Llasat, M. C., and Rodríguez, R.: Potencialidad del índice NAO en la previsión de episodios de alta pluviometría en España, Madrid, Fundación Mpfre, Estudios Gerencia de Riesgos, 67, 19-29, 1999.

Molina, R., Muntán, E., Andreu, L., Furdada, G., Oller, P., Gutiérrez, E., Martínez, P., and Vilaplana, J. M.: Using vegetation to characterize the avalanche of Canal del Roc Roig, Vall de Núria, eastern Pyrenees, Spain, Ann. Glaciol., 38, 159-165, 2004.

Mundo, I. A., Barrera, M. D., and Roig, F. A.: Testing the utility of Nothofagus pumilio for dating snow avalanche in Tierra del Fuego, Argentina, Dendrochronologia, 25, 19-28, 2007.

Muntán, E., Andreu, L., Oller, P., Gutiérrez, E., and Martínez, P.: Dendrochronological study of the avalanche path Canal del Roc Roig, First results of the ALUDEX project in the Pyrenees, Ann. Glaciol., 38, 173-179, 2004.
Muñoz, P.: Prevención y defensa contra aludes, aplicación práctica al Pirineo aragonés, unpublished Ph.D thesis, Universidad Politécnica de Madrid, Escuela Superior de Ingenieros de Montes, Madrid and Instituto Pirenaico de Ecología, Jaca, 498 pp., 1988.

Potter Jr., N.: Tree-ring dating of snow avalanche tracks and the geomorphic activity of avalanches, Northern Absaroka Mountains, Wyoming, Geological Society of America, Inc., 123, 141-165, 1969.

Reardon, B. A., Pederson, G. T., Caruso, C. J., and Fagre, D. B.: Spatial reconstructions and comparisons of historic avalanche frequency and extent using tree rings in Glacier National Park, Montana, USA, Arct. Antarct. Alp. Res., 40(1), 148-160, 2008.

Schaerer, P.: Winter weather patterns for major avalanches, The avalanche review, 4(3), 2 pp., 1986.

Shroder Jr., J. F.: Dendrogeomorphological analysis of mass movement on Table Cliffs Plateau, Utah, Quaternary Res., 9, 168-185, 1978.

Stoffel, M., Bollschweiler, M., and Hassler, G. R.: Differentiating events on a cone influenced by debris-flow and snow avalanche activity - a dendrogeomorphological approach, Earth Surf. Proc. Land., 31(11), 1424-1437, 2006.

Stokes, M. A. and Smiley, T. L.: An introduction to tree-ring dating, University of Chicago Press, 1968. 